\title{
Pengaruh Corporate Governance Terhadap Financial disstres
}

\author{
Ayu Aditia Hariyani ${ }^{*}$, Andi Kartika ${ }^{2}$ \\ Universitas Stikubank Semarang, Indonesia \\ ayuaah05@mail.com, andikartika@edu.unisbank.ac.id
}

*Penulis Korespondensi

Dikirim : 16 April 2021

Diterima : 27 April 2021

Dipublikasi : 1 Agustus 2021

\begin{abstract}
This study aims to test and find empirical evidence regarding the effect of corporate governance described by managerial ownership, institutional ownership, independent commissioners, audit committee on financial distress in manufacturing companies listed on the IDX for the 2017-2019 period. In this study, leverage, profitability and company size are used as control variables. The population in this study are all manufacturing companies listed on the Indonesia Stock Exchange (BEI) 2017-2019. In this study the sample was selected using purposive sampling method and obtained a sample of 361 companies. The analytical tool used in this research is logistic regression. The test results show that managerial ownership has no effect on financial distress. Meanwhile, institutional ownership has an effect on financial distress, independent commissioners have an effect on financial distress and the audit committee also has an effect on financial distress. Leverage as a control variable shows results that are not in accordance with its function, namely it does not affect financial distress, as well as the control variable company size which states results that are not in accordance with its function, namely it does not affect financial distress, in contrast to profitability as a control variable shows results in accordance with its function and affects financial distress.
\end{abstract}

Keywords: company size; corporate governance; financial distress; leverage; profitability

\section{PENDAHULUAN}

Fenomena yang terjadi di Indonesia adalah delisting nya beberapa perusahaan pada tahun 2017. Delisting dilakukan karena saham yang tercatat di Bursa hadapi penyusutan kriteria sehingga tidak penuhi persyaratan pencatatan. Tindakan penghapusan pencatatan saham dari daftar saham yang tercatat di bursa juga dapat dilakukan permohonan pihak emiten sendiri atau disebut dengan voluntary delisting. Kasus pada PT Ciputra Property Tbk (CTRP) dan PT Ciputra Surya Tbk (CTRS), delisting karena adanya penggabungan dengan perusahaan CTRA, PT Sorini Agro Asia Corporindo Tbk (SOBI) delisting karena tiga alasan utama antara lain: Pertama saham SOBI yang dimiliki oleh investor hanya 1,32\% sehingga tidak aktif diperdagangkan oleh BEI dan relatif tidak likuid. Kedua, perseroan menyatakan bahwa tidak memerlukan penggalangan dana dari pemegang saham publik. Ketiga, SOBI tidak bisa memenuhi ketentuan dari BEI no I-A yang memilik free float 50 juta lembar sehaam dan 7,5\% saham dimiliki oleh investor publik. PT Citra Maharlika Nusantara Corpora Tbk (CPGT) delisting karena perusahaan tersebut mengalami kepailitan sejak 28 April 2017 (www.sahamok.net).

Kondisi finansial distress yang dialami oleh perusahaan manufaktur maupun perusahaan sektor lainnya dapat diketahui dengan menggunakan berbagai indikator kinerja keuangan yang diperoleh dari analisis rasio keuangan yang terdapat pada informasi laporan keuangan yang diterbitkan oleh masing-masing perusahaan. Indikator selain kinerja keuangan yang digunakan dalam memprediksi terjadinya financial distress, yaitu mekanisme corporate governance yang ada dalam perusahaan. Mekanisme Corporate Governance yang dapat diwujudkan dengan adanya 
berbagai pihak yang terlibat seperti, Kepemilikan Institusional, Kepemilikan Manajerial, Komisaris Inependen dan Komite Audit.

Penelitian ini dilakukan karena banyaknya kasus delisting yang terjadi di Indonesia sehingga hasil dari penelitian ini diharapkan dapat mengembangkan pengetahuan khususnya dibidang akuntansi tentang faktor-faktor yang mempengaruhi finansial distress dan yang berkaitan dengan tata kelola perusahaan pada tanggung jawab sosial dan nilai financial distress, serta dapat dijadikan referensi dan perandingan dalam melakukan penelitian yang akan datang. Bagi investor ataupun calon investor juga dapat menjadikan penelitian ini sebagai bahan pertimbangan dalam mengambil keputusan yang berkaitan dengan financial distress. Tujuan dalam penelitian ini juga untuk menguji kepemilikan manajerial, kepemilikan institusional, komisaris independen dan komite audit apakah berpengaruh terhadap financial distress.

Kepemilikan Manajerial adalah jumlah kepemilikan saham oleh pihak manajemen dari seluruh modal aham perusahaan yang dikelola _(Putri, 2020). Peneliti yang dilakukan _(Hanafi \& Breliastiti, 2016) menunjukkan bahwa kepemilikan manajerial berpengaruh negatif terhadap financial distress. Sebaliknya, hasil peneliti yang dilakukan _(Ayu, Yulianeu, \& Fathuni, 2017) menunjukkan bahwa kepemilikan manajerial tidak berpengaruh terhadap financial distress. Kepemilikan institusional merupakan proporsi saham biasa yang dimiliki oleh para pihak intitusional (Helena \& Saifi, 2018). Penelitian yang dilakukan_(Rahmawati \& Khoiruddin, 2017), (Ayu, Yulianeu, \& Fathuni, 2017) menunjukkan bahwa kepemilikan institusional berpengaruh negatif terhadap finansial distress. Sebaliknya, hasil peneliti yang dilakukan _(Yudha \& Fuad, 2014) menunjukkan bahwa kepemilikan institusional tidak berpengaruh negatif terhadap financial distress. Komisaris Independen dalam menjalankan perusahaan memiliki fungsi dalam mengawasi penerapan good corpoate governance sekaligus kinerja direksi. (Mafiroh \& Triyono, 2016). Penelitian yang dilakukan oleh_(Rahmawati \& Khoiruddin, 2017) menunjukkan bahwa ukuran dewan komisaris independen berpengaruh dengan arah negatif terhadap finansial distress. Sebaliknya, hasil peneliti yang dilakukan_(Helena \& Saifi, 2018) menunjukkan bahwa ukuran dewan komisaris tidak berpengaruh terhadap finansial distress. Komite Audit merupakan suatu badan yang secara profesional bekerja, dan dibentuk oleh dewan komisaris secara independen untuk membantu dan memperkuat fungsi dewan komisaris dalam melaksanakan pengawasan atas proses pelaporan keuangan ,manajemen risiko, dan pelaksanaan audit implementasi corporate governance (Putri, 2020). Penelitian yang dilakukan_(Mafiroh A. , 2016) menunjukkan bahwa komite audit berpengaruh negatif terhadap finansial distress. Sebaliknya, hasil peneliti yang dilakukan_(Ananto, Mustika, \& Handayani, 2017) dan_(Helena \& Saifi, 2018) menunjukkan bahwa komite audit tidak berpengaruh finansial distress, yang menjelaskan jika mekanisme corporate governance tidak ada pengaruhnya terhadap kebangkrutan.

Perbedaan dalam penelitian ini adalah menggunakan leverage, profitabilitas dan ukuran perusahaan sebagai variabel kontrol. Semakin besar hutang perusahaan semakin besar kemungkinan perusahaan mengalami financial distress dan semakin tinggi profitabilitas, semakin efisien perusahaan dalam penggunaan aset perusahaan yang akan mengurangi biaya usaha dan semakin kecil perusahaan mengalami financial distress _(Mafiroh \& Triyono, 2016). Penelitian terdahulu mengenai leverage terhadap financial distress menunjukkan hasil yang tetap. Penelitian yang dilakukan (Putri, 2020) mengatakan bahwa leverage mempunyai pengaruh positif signifikan terhadap financial distress. Hal tersebut sejalan dengan penelitian _(Mafiroh \& Triyono, 2016), sedangkan pada penelitian (Yoon \& Jang, S, 2005) menyatakan bahwa leverage berpengaruh negatif signifikan. Profitabilitas terhadap financial distress menunjukkan hasil yang tetap juga. Penelitian yang dilakukan _(Rahmawati \& Khoiruddin, 2017) menemukan bahwa profitabilitas berpengaruh negatif terhadap financial distress. Hal ini sejalan dengan penelitian _(Ayu, Yulianeu, \& Fathuni, 2017) dan_(Mafiroh \& Triyono, 2016). Ukuran perusahaan terhadap financial distress mengatakan bahwa ukuran perusahaan memiliki pengaruh signifikan dan memiliki arah negatif terhadap financial distress _(Ayu, Yulianeu, \& Fathuni, 2017) dan _(Rahmawati \& Khoiruddin, 2017), sedangkan penelitian pada _(Ananto, Mustika, \& Handayani, 2017) mengatakan bahwa ukuran perusahaan tidak memiliki pengaruh terhadap financial distress. 


\section{Teori Keagenan (Agency Theory)}

\section{STUDI LITERATUR}

(Smulowitz et al., 2019) berkata jika teori keagenan ( agency theory) merupakan teori yang menarangkan terdapatnya ikatan kerja antara pihak yang memberikan wewenang (principal) yakni investor ataupun pemegang saham dengan pihak yang menerima wewenang ( agent) yakni manajer dalam wujud kontrak kerja sama. Teori keagenan mengasumsikan jika seluruh orang berperan atas kepentingan mereka sendiri. Pemegang saham selaku principal diprediksi hanya tertarik pada hasil keuangan yang meningkat ataupun investasi mereka di dalam industri, sebaliknya para agent diasumsikan menerima kepuasan berbentuk kompensasi keuangan serta syarat- syarat yang menyertai dalam ikatan tersebut. Bila ikatan kerja antara principal serta agent bisa berjalan dengan baik sehingga tujuan yang akan dicapai bisa terlaksana.

\section{Financial Distress}

Kesusahan keuangan merupakan kondisi arus kas industri tidak layak dalam penuhi kewajibannya disaat ini, kemudian industri dituntut agar mengambil aksi korektif. Financial distress didefinisikan selaku tahap penyusutan kondisi yang terjalin saat sebelum terbentuknya kebangkrutan ataupun saat sebelum industri dilikuidasi. Variabel financial distress dapat didefinisikan sebagai perusahaan yang memiliki laba per saham (earning per share) negatif (Hanafi \& Breliastiti, 2016).

Perhitungan dapat dilakukan sebagai berikut:

Keterangan :

$$
E P S=\frac{\text { Laba Bersih }}{\text { Lembar Saham yang Beredar }}
$$

EPS positif $=$ non financial distress $=1$

EPS negatif $=$ financial distress $=0$

\section{Kepemilikan Manajerial}

Kepemilikan manajerial ialah saham yang dimiliki pihak manajemen yang terdiri dari direksi, manajer dan dewan komisaris dalam bentuk \%. Beberapa saham milik komisaris juga direksi merupakan bagian dari kepemilikan saham manajerial. Pada variabel ini ditunjukan menggunakan presentase saham oleh manajerial dari total saham beredar yang dimiliki perusahaan (Damayanti \& Kusumaningtias, 2020).

$$
\text { KEPMAN }=\frac{\text { Jumlah Saham Yang Dimiliki Manajerial }}{\text { Jumlah Saham Yang Beredar }} 100 \%
$$

\section{$\mathrm{H}_{1}$ :Kepemilikan Manajerial Berpengaruh Negatif Terhadap Financial Distress}

\section{Kepemilikan Institusional}

Kepemilikan institusional adalah persentase saham yang dimiliki oleh institusi dari keseluruhan saham perusahaan yang beredar _(Damayanti \& Kusumaningtias, 2020). Variabel ini kemudian dihitung dengan menggunakan jumlah saham yang dimiliki pihak institusi dengan total jumlah saham beredar perusahaan (Hanafi \& Breliastiti, 2016).

$$
\text { KEPINST }=\frac{\text { Jumlah Saham Yang Dimiliki Institusi }}{\text { Jumlah Saham Yang Beredar }} 100 \%
$$

\section{$\mathrm{H}_{2}$ :Kepemilikan Institusional Berpengaruh Positif Terhadap Financial Distress}

\section{Komisaris Independen}

Komisaris independen yaitu sebagai anggota dari dewan komisaris yang tidak memilik hubungan apapun dengan pihak manajerial perusahaan. Komisaris independen diukur menggunakan presentase anggota dengan total komisaris perusahaan (Damayanti \& Kusumaningtias, 2020).

$$
\text { KOM_INDEP }=\frac{\text { Dewan Komisaris Independen }}{\text { Jumlah Dewan Komisaris }} 100 \%
$$




\section{$\mathrm{H}_{3}$ :Komisaris Independen Berpengaruh Positif Terhadap Financial Distress}

\section{Komite Audit}

Kompetensi komite audit menjadi salah satu karakteristik yang penting untuk memastikan bahwa komite audit melaksanakan tugas mereka secara efektif. Memperkuat pengawasan berterkaitan dengan laporan keuangan, manajemen risiko, implementasi tata kelola juga terhubung dengan pelaksanaan audit untuk perusahaan adalah pengertian komite audit (Damayanti \& Kusumaningtias, 2020). Pengukuran komite audit ialah Total seluruh anggota komite audit dalam periode $\mathrm{t}$ (Hartantri \& Elsye Hatane, 2017).

\section{KOM_AUDIT $=\sum$ Komite Audit Periode $t$}

\section{$\mathrm{H}_{4}$ :Komite Audit Berpengaruh Positif Terhadap Financial Distress}

\section{Leverage}

Leverage merupakan rasio yang digunakan untuk mengukur sejauh mana kemampuan perusahaan untuk membayar hutang dengan aktivanya_(Ananto, Mustika, \& Handayani, 2017). Leverage digunakan sebagai kontrol dengan skala rasio dari total keajiban dibagi dengan total aset yang digunakan_(Anjana, 2017).

$$
\text { Laverage }=\frac{\text { Total Utang }}{\text { Total Asset }}
$$

\section{Profitabilitas}

Profitabilitas menunjukkan efisiensi dan efektivitas penggunaan aset perusahaann karena rasio ini mengukur perusahaan menghasilkan laba berdasarkan penggunaan aset. Dengan adanya efektivitas penggunaan aset perusahaan maka akan mengurangi biaya yang dikeluarkan oleh perusahaan, sehingga perusahaan akan memperoleh penghematan dan akan memiliki kecukupan dana untuk menjalankan usahanya (Ananto et al., 2017). Profitabilitas digunakan sebagai kontrol dengan skala rasio dari total laba bersih dibagi dengan total aktivat yang digunakan (Mafiroh \& Triyono, 2016).

$$
\text { Profitabilitas }=\frac{\text { Laba Bersih }}{\text { Total Aset }}
$$

\section{Ukuran Perusahaan}

Ukuran perusahaan adalah variabel yang menggambarkan besar kecilnya perusahaan. Firm Size / Ukuran Perusahaan digunakan untuk menentukan perusahaan besar dan kecil dalam penelitian ini dengan cara rata-rata total asset. Apabila hasilnya di atas rata-rata tersebut maka digolongkan sebagai perusahaan besar apabila di bawah maka dikatakan perusahaan kecil (Hartantri \& Elsye Hatane, 2017).

$$
\text { size }=\ln (\text { Total Aset })
$$

\section{METODE}

Jenis penelitian ini merupakan penelitian kuantitatif dengan data yang digunakan yaitu data sekunder yang bersumber dari laporan keuangan tahunan perusahaan manufaktur yang terdaftar di Bursa Efek Indonesia tahun 2017-2019. Metode pemilihan sampel yang digunakan dalam penelitian ini adalah purposive sampling, sedangkan metode pengumpulan data yang digunakan dalam penelitian ini adalah metode dokumenter, yaitu teknik pengambilan data dengan cara mengumpulkan, mencatat dan mengkaji data sekunder yang berupa laporan keuangan perusahaan manufaktur yang dipublikasikan oleh Bursa Efek Indonesia tahun 2017-2019.

\section{Populasi dan Sempel}

Populasi dalam riset ini merupakan seluruh industri manufaktur yang terdaftar di Bursa Efek Indonesia( BEI) sejak tahun 2017- 2019. Dari populasi riset diperoleh sampel riset sebanyak 361 data. Pengambilan sampel riset ini memakai tata cara purposive sampling ialah sampel 
Owner: Riset \& Jurnal Akuntansi

e-ISSN : 2548-9224 |p-ISSN : 2548-7507

Volume 5 Nomor 5, Agustus 2021

DOI : https://doi.org/10.33395/owner.v5i2.413

diseleksi dengan memakai pertimbangan yang penuhi kriteria- kriteria tertentu dan cocok dengan tujuan riset. Ada pula kriteria dalam pengambilan sampel yang hendak diteliti yaitu sebagai berikut:

Tabel 1. Seleksi Sampel.

\begin{tabular}{|c|l|c|c|c|c|}
\hline No & \multicolumn{1}{|c|}{ Keterangan } & $\mathbf{2 0 1 7}$ & $\mathbf{2 0 1 8}$ & $\mathbf{2 0 1 9}$ & Total \\
\hline & Populasi & & & & \\
\cline { 2 - 6 } & $\begin{array}{l}\text { Perusahaan manufaktur yang terdaftar di Bursa Efek } \\
\text { Indonesia dari tahun 2017 hingga tahun 2019. }\end{array}$ & 156 & 166 & 182 & 504 \\
\hline \multirow{2}{*}{1.} & $\begin{array}{l}\text { Kriteria Sampel } \\
\text { Perusahaan manufaktur yang tidak secara konsisten } \\
\text { terdaftar di BEI pada tahun 2017, 2018 dan 2019. }\end{array}$ & $(0)$ & $(10)$ & $(26)$ & $(36)$ \\
\hline \multirow{2}{*}{2.} & $\begin{array}{l}\text { Perusahaan manufaktur yang tidak memakai satuan } \\
\text { mata uang Rupiah (Rp). }\end{array}$ & $(29)$ & $(29)$ & $(29)$ & $(87)$ \\
\hline \multirow{2}{*}{3.} & $\begin{array}{l}\text { Perusahaan manufaktur yang tidak menyediakan data } \\
\text { secara lengkap dalam variabel penelitian. }\end{array}$ & $(1)$ & $(1)$ & $(0)$ & $(2)$ \\
\hline 4. & $\begin{array}{l}\text { Perusahaan manufaktur yang tidak melaporkan laporan } \\
\text { tahunan (annual report) tahun 2017 hingga tahun 2019. }\end{array}$ & $(6)$ & $(5)$ & $(7)$ & $(18)$ \\
\hline & Total Sampel Perusahaan Manufaktur & 120 & 121 & 120 & 361 \\
\hline
\end{tabular}

Sumber : Idx, diolah oleh peneliti 2021.

\section{Statistika Deskriptif}

\section{HASIL}

Statistika deskriptif digunakan untuk membagikan cerminan tentang informasi yang bisa dilihat dari nilai minimum, nilai maksimum, rata- rata ( mean), serta standar deviasi. Tabel 2 menyajikan hasil statistik deskriptif variabel financial distress, kepemilikan manajerial, kepemilikan institusional, komisaris independen, komite audit, leverage, profitabilitas serta ukuran perusahaan sebagai berikut:

Tabel 2. Statistika Deskriptif

\begin{tabular}{|l|r|r|r|r|r|}
\hline \multicolumn{7}{|c|}{ Descriptive Statistics } \\
\hline & \multicolumn{1}{|c|}{$\mathrm{N}$} & Minimum & Maximum & \multicolumn{1}{c|}{ Mean } & Std. Deviation \\
\hline FD & 361 & .0000 & 1.0000 & .177285 & .3824400 \\
\hline PROPORSI KM & 361 & .0000 & .7392 & .053436 & .1254719 \\
\hline PROPORSI KI & 361 & .0000 & 1.0000 & .668857 & .2360880 \\
\hline PROPORSI DEW KOM INDE & 361 & .0000 & 1.0000 & .418873 & .1139161 \\
\hline KOM AU & 361 & .0000 & 5.0000 & 3.005540 & .4013481 \\
\hline LEV & 361 & .0651 & 4.9418 & .523547 & .4890738 \\
\hline PROF & 361 & -2.6410 & .7160 & .042695 & .1765443 \\
\hline UP & 361 & 12.5969 & 31.4310 & 24.175015 & 5.1351839 \\
\hline Valid N (listwise) & 361 & & & & \\
\hline
\end{tabular}

Sumber : output SPSS 2021 
Tabel 4.2 menyajikan Statistika Deskriptif setelah transformasi. Menunjukkan bahwa jumlah $(\mathrm{N})$ yang diteliti sebanyak 361 perusahaan manufaktur yang terdaftar di Bursa Efek Indonesia selama tahun 2017- 2019.

Variabel financial distress perusahaan manufaktur periode 2017-2019 memiliki rata-rata (mean) sebear 0,18 dengan stadar deviasi sebesar 0,382. Nilai minimum dan maksimum masingmasing adalah 0 dan 1 .

Nilai rata- rata kepemilikan manajerial (PROPORSI KM) dari tahun 2017-2019 sebesar 0,053436 dengan nilai standar deviasi sebesar 0,1254719 . Nilai minimum sebesar 0,0000 yaitu pada PT Akasha Wira International Tbk tahun 2017, sedangkan nilai maksimalnya sebesar 0,7392 yaitu pada PT Saranacentral Bajatama Tbk tahun 2019.

Nilai rata-rata kepemilikan institusional (PROPORSI KI) dari tahun 2017-2019 sebesar 0,668875 dengan nilai standar deviasi sebesar 0,2360880. Nilai minimum sebesar 0,0000 yaitu pada PT Saranacentral Bajatama Tbk tahun 2018, sdangkan nilai maksimalnya sebesar 1,0000 pada PT Trisula Textile Industries Tbk tahun 2019.

Nilai rata-rata komisaris independen mulai tahun 2017-2019 sebesar 0,418873 dengan nilai standar deviasi sebesar 0,1139161. Nilai minimum sebesar 0,0000 yaitu pada PT Tiga Pilar Sejahtera Food Tbk tahun 2019, sedangkan nilai maksimalnya sebesar 1,0000 pada PT Bentoel Internasional Investam tahun 2018.

Nilai rata-rata komite audit mulai tahun 2017-2019 sebesar 3,005540 dengan nilai standar deviasi sebesar 0,4013481. Nilai minimum sebesar 0,0000 yaitu pada PT Tiga Pilar Sejahtera Food Tbk tahun 2018, sedangkan nilai maksimalnya sebesar 5,0000 pada PT Malindo Feedmill Tbk tahun 2017.

Nilai rata-rata leverage dari tahun 2017-2019 sebesar 0,523547 dengan nilai standar deviasi sebesar 0,4890738. Nilai minimum sebesar 0,0651 yaitu pada PT Multi Prima Sejahtera Tbk tahun 2019, sedangkan nilai maksimalnya sebesar 4,9418 yaitu pada PT Astra International Tbk tahun 2018.

Nilai rata-rata profitabilitas dari tahun 2017-2019 sebesar 0,042695 dengan nilai standar deviasi sebesar 0,1765443. Nilai minimum sebesar -2,6410 yaitu pada PT Tiga Pilar Sejahtera Food Tbk tahun 2017, sedangkan nilai maksimalnya sebesar 0,7160 yaitu pada PT Multi Prima Sejahtera Tbk tahun 2017.

Nilai rata-rata ukuran perusahaan dari tahun 2017-2019 sebesar 24,175015 dengan nilai standar deviasi sebesar 5,1351839. Nilai minimum sebesar 12,5969 yaitu pada PT Astra International Tbk tahun 2017, sedangkan nilai maksimalnya sebesar 31,4310 yaitu pada PT Indomobil Sukses Internasional tahun 2019.

\section{Uji Kelayakan Model (Goodness of Fit Test)}

Kelayakan model regresi dapat dilihat menggunakan Hosmer and Lemeshow's Goodness of Fit Test. Berikut ini adalah hasil pengujian Hosmer and Lemeshow's Goodness of Fit Test, yaitu:

Tabel 3. Hasil Pengujian Hosmer and Lemesho's Test

\begin{tabular}{|c|c|c|c|}
\hline \multicolumn{4}{|c|}{ Hosmer and Lemeshow Test } \\
\hline Step & Chi-square & df & Sig. \\
\hline 1 & .147 & 8 & 1.000 \\
\hline
\end{tabular}

Sumber : output SPSS 2021

Dari tabel 3 memperlihatkan bahwa Hosmer andLemeshow's Goodness of Fit memiliki nilai statistik sebesar 0,147 dan nilai signifikansi 1,000. Saat nilai signfikansi lebih besar dari 0,05 maka bisa disimpulkan bahwa hipotesis diterima berarti model mampu memprediksi nilai observasinya atau model dapat dikatakan fit dan dapat diterima karena cocok dengan data observasinya(Ghozali, 2011).

Uji Kelayakan Keseluruhan Model (Overall Model Fit Test) 
Owner: Riset \& Jurnal Akuntansi

e-ISSN : 2548-9224 |p-ISSN : 2548-7507

Volume 5 Nomor 5, Agustus 2021

DOI : https://doi.org/10.33395/owner.v5i2.413

\section{Chi Square Test}

Pengujian chi square dilakukan dengan dibandingkan nilai antara -2 log likelihood awal (block number 0) dengan nilai -2 log likelihood akhir (block number 1). Apanila mengalami penurunan, maka model ini menunjukkan bahwa model regresi ini baik.

Block 0

Tabel 4. Likelihood Overall Test

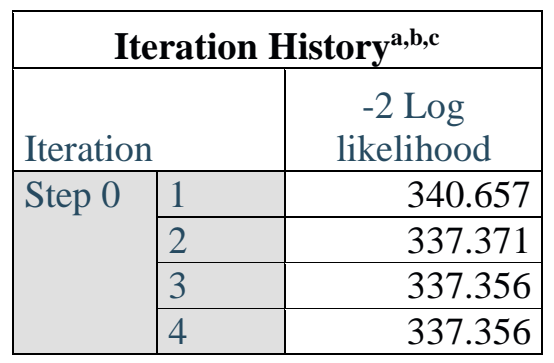

Blok 1

Sumber : output SPSS 2021

\begin{tabular}{|c|c|c|}
\hline \multicolumn{3}{|c|}{ Iteration History $^{\mathrm{a}, \mathrm{b}, \mathrm{c}, \mathrm{d}}$} \\
\hline \multicolumn{2}{|c|}{ Iteration } & $\begin{array}{l}-2 \log \\
\text { likelihood }\end{array}$ \\
\hline \multirow{13}{*}{ Step 1} & 1 & 276.447 \\
\hline & 2 & 189.44 \\
\hline & 3 & 121.243 \\
\hline & 4 & 81.183 \\
\hline & 5 & 58.883 \\
\hline & 6 & 46.439 \\
\hline & 7 & 39.952 \\
\hline & 8 & 37.535 \\
\hline & 9 & 37.095 \\
\hline & 10 & 37.076 \\
\hline & 11 & 37.076 \\
\hline & 12 & 37.076 \\
\hline & 13 & 37.076 \\
\hline
\end{tabular}

Sumber : output SPSS 2021

Hasil uji Block Number 0 diperoleh nilai -2 log likelihood sebesar 337,356 sedang pada Block Number 1 diperoleh nilai -2 log likelihood sebesar 37,076. Hal ini menunjukkan adanya penurunan nilai -2 log likelihood. Turunnya nilai -2 log likelihood menunjukkan model regresi yang dihipotesiskan fit dengan data.

Turunnya nilai -2 log likelihood tersebut disajikan pada nilai chi square dalam omnibus test of model coefficient sebagai berikut:

Tabel 5. Omnibus test of model coefficient

\begin{tabular}{|l|l|r|r|r|}
\hline \multicolumn{5}{|c|}{ Omnibus Tests of Model Coefficients } \\
\hline \multirow{3}{|c|}{ Step 1 } & Step & 300.280 & \multicolumn{1}{c|}{ Chi-square } & \multicolumn{1}{c|}{ Sig. } \\
\cline { 2 - 5 } & Block & 300.280 & 7 & .000 \\
\cline { 2 - 5 } & Model & 300.280 & 7 & .000 \\
\hline
\end{tabular}

Sumber : output SPSS 2021 
Dari hasil pengujian omnibus test pada tabel 4.5 diperoleh nilai chi square (penurunan nilai -2 log likelihood) sebesar 300,280 dengan nilai signifikan sebesar 0,000 Nilai signifikan yang lebih rendah dari 0,05 menunjukkan adanya pengaruh yang signifikan dari variabel independen terhadap variabel dependennya.

\section{Cox and Snell's $R$ Square dan Nagelkereke's $R$ Square}

Analisis nilai Cox and Snell's $R$ Square dilakukan untuk mengukur sejauh mana model dalam menerangkan variasi variabel independen terhadap variabel dependen. Dengan cara membagi nilai Cox and Snell's R Square dengan nilai maksimal. Hasil uji Cox and Snell's R Square dan Nagelkereke's $R$ Square diperlihatkan pada tabel 6 berikut:

Tabel 6. Cox and Snell's R Square dan Nagelkereke's $R$ Square

\begin{tabular}{|l|c|c|c|}
\hline \multicolumn{4}{|c|}{ Model Summary } \\
\hline Step & $\begin{array}{c}-2 \text { Log } \\
\text { likelihood }\end{array}$ & $\begin{array}{c}\text { Cox \& Snell R } \\
\text { Square }\end{array}$ & $\begin{array}{c}\text { Nagelkerke R } \\
\text { Square }\end{array}$ \\
\hline 1 & $37.076^{\mathrm{a}}$ & .565 & .930 \\
\hline
\end{tabular}

Sumber : output SPSS 2021

Berdasarkan tabel 4.6 menunjukkan bahwa nilai Nagellkerke $R$ Squere sebesar 0,930 atau 93,0\% yang berarti sebesar 93\% variabel financial distress dapat dijelaskan oleh variabel kepemilikan manajerial, kepemilikan institusional, komisaris independen, komite audit, leverage, profitabilitas dan ukuran perusahaan, sedangkan $7,0 \%$ sisanya dijelaskan variabel lain diluar model.

\section{Tabel Klasifikasi $2 \times 2$}

Tabel klasifikasi memperlihatkan kekuatan prediksi pada suatu model regresi untuk melihat kemungkinan perusahaan mengalami financial distress. Tabel klasifikasi $2 \times 2$ menghitung nilai estimasi yang benar (correct) dan salah (incorrect) pada variabel dependen.

Tabel 7. Tabel Klasifikasi 2x2

\begin{tabular}{|c|c|c|c|c|c|}
\hline \multicolumn{6}{|c|}{ Classification Table $^{\mathbf{a}}$} \\
\hline \multirow{3}{*}{\multicolumn{3}{|c|}{ Observed }} & \multicolumn{3}{|c|}{$\begin{array}{r}\text { Predicted } \\
\end{array}$} \\
\hline & & & \multicolumn{2}{|c|}{ FD } & \multirow{2}{*}{$\begin{array}{c}\text { Percentage } \\
\text { Correct }\end{array}$} \\
\hline & & & .0000 & 1.0000 & \\
\hline \multirow[t]{3}{*}{ Step 1} & \multirow[t]{2}{*}{ FD } & .0000 & 295 & 2 & 99.3 \\
\hline & & 1.0000 & 5 & 59 & 92.2 \\
\hline & \multicolumn{2}{|c|}{ Overall Percentage } & & & 98.1 \\
\hline
\end{tabular}

Sumber : output SPSS 2021

Berdasarkan tabel 4.7 menunjukkan bahwa dari 297 sampel perusahaan memiliki keuangan yang sehat (non financial distress), 295 perusahaan atau 99,3\% (295/297) sampel secara tepat diprediksi oleh model regresi dan 2 perusahaan tidak tepat diprediksi oleh model. Selain itu dari 64 sampel perusahaan yang mengalami financial distress, 59 perusahaan atau 92,2 \% (59/64) sampel dapat diprediksi oleh model, dan 5 perusahaan tidak dapat diprediksi oleh model. Secara keseleruhan terdaapat $295+59=354$ perusahaan dari 361 sampel perusahaan atau 98,1\% (354/361) sampel dapat diprediksi dengan tepat oleh model regresi. Dengan demikian, dapat disimpulkan bahwa tingginya presentase tersebut mendukung tidak adanya perbedaan yang signifikan antara data hasil prediksi dan data observasinya, sehingga menunjukkan model regresi yang baik.

\section{Pengujian Hipotesis}

Penyajikan hasil hipotesis pada tabel 8 sebagai berikut: 
Tabel 8. Hasil Uji Hipotesis

\begin{tabular}{|c|c|c|c|c|c|c|c|}
\hline \multicolumn{8}{|c|}{ Variables in the Equation } \\
\hline & & $\mathrm{B}$ & S.E. & Wald & $\mathrm{df}$ & Sig. & $\operatorname{Exp}(B)$ \\
\hline \multirow[t]{8}{*}{ Step $1^{a}$} & PROPORSI KM & 3.214 & 4.630 & .482 & 1 & .488 & 24.874 \\
\hline & PROPORSI KI & 6.022 & 2.974 & 4.100 & 1 & .043 & 412.491 \\
\hline & $\begin{array}{l}\text { PROPORSI DEW } \\
\text { KOM INDE }\end{array}$ & -13.279 & 5.300 & 6.277 & 1 & .012 & .000 \\
\hline & KOM AU & 3.865 & 1.311 & 8.692 & 1 & .003 & 47.704 \\
\hline & LEV & .030 & .642 & .002 & 1 & .963 & 1.030 \\
\hline & PROF & -285.651 & 72.389 & 15.571 & 1 & .000 & .000 \\
\hline & UP & .147 & .103 & 2.027 & 1 & .155 & 1.158 \\
\hline & Constant & -15.595 & 5.049 & 9.539 & 1 & .002 & .000 \\
\hline
\end{tabular}

Sumber : output SPSS 2021

Hasil dari tabel 8 diatas memperoleh model regresi sebagai berikut: Ln $\frac{P}{1-P}=-15,595+3,214$ PROPORSI KM $+6,022$ PROPORSI KI -13279 PROPORSI DEW KOM INDE+ 3,865 KOM AU + 0,030 LEV - 285,651 PROF + 0,147 UP + e

Pada variabel kepemilikan manajerial mendapatkan nilai koefisien beta sebesar 3,214 dan nilai signifikansi 0,488 yang nilainya lebih besar dari 0,05 . Maka $H_{1}$ ditolak.

Pada variabel kepemilikan institusional mendapatkan nilai koefisien beta sebesar 6,022 dan nilai signifikansi 0,043 yang nilainya lebih kecil dari 0,05 . Maka $H_{2}$ diterima.

Pada variabel komisaris independen mendapatkan nilai koefisien beta sebesar -13,279 dan nilai signifikansi 0,012 yang nilainya lebih kecil dari 0,05 . Maka $H_{3}$ diterima.

Pada variabel komite audit mendapatkan nilai koefisien beta sebesar 3,865 dan nilai signifikansi 0,003 yang nilainya lebih kecil dari 0,05 . Maka $H_{4}$ diterima.

Pada leverage sebagai variabel kontrol mendapatkan nilai koefisien beta sebesar 0,030 dan nilai signifikansi 0,963 yang nilainya lebih besar dari 0,05 . Maka leverage tidak berpengaruh terhadap financial distress.

Pada profitabilitas sebagai variabel kontrol mendapatkan nilai koefisien beta sebesar 285,651 dan nilai signifikansi 0,000 yang nilainya lebih kecil dari 0,05. Maka profitabilitas berpengaruh terhadap financial distress.

Ukuran perusahaan sebagai variabel kontrol mendapatkan nilai koefisien beta sebesar 0,147 dan nilai signifikansi 0,155 yang nilainya lebih besar dari 0,05 . Maka ukuran perusahaan tidak berpengaruh terhadap financial distress.

\section{PEMBAHASAN}

\section{Pengaruh Kepemilikan Manajerial Terhadap Financial distress}

Dari hasil uji regresi logistik memperlihatkan bahwa kepemilikan manajerial tidak berpengaruh terhadap financial distress. Hasil penelitian ini menolak hipotesis pertama $\left(\mathrm{H}_{1}\right)$ yang mengatakan bahwa kepemilikan manajerial berpengaruh negatif terhadap financisl distress. Hasil tersebut berbeda dengan agency theory yang mengatakan bahwa semakin tiggi kepemilikan manajerial maka semakin kecil terjadinya financial distress. Hasil penelitian tersebut sesuai dengan penelitian (Yudha, 2014), (Santoso et al., 2018) yang menyatakan bahwa kepemilikan manajerial tidak berpengaruh terhadap financial distress. Akan tetapi berbeda dengan penelitian (Rahmawati \& Khoiruddin, 2017) yang mengatakan bahwa kepemilikan manajerial berpengaruh terhadap financial distress.

\section{Pengaruh Kepemilikan Institusional Terhadap Financial Distress}

Dari hasil uji regresi logistik mengemukakan bahwa kepemilikan institusional berpengaruh terhadap financial disress. Dari hasil penelitian ini menerima hipotesis kedua $\left(\mathrm{H}_{2}\right)$ yang mengatakan bahwa kepemilikan institusional berpengaruh positif terhadap financial distress. Besarnya kepemilikan institusional sangat berpengaruh pada perusahaan yang akan berdampak pada besarnya nilai modal yang dapat dipergunakan untuk melakukan aktivitas operasional 
perusahaan. Hasil penelitian ini sesuai dengan penelitian yang dilakukan oleh (Yudha, 2014), (Damayanti \& Kusumaningtias, 2020) yang mengatakan bahwa kepemilikan institusional berpengaruh terhadap financial distress. Namun berbeda dengan penelitian(Ananto et al., 2017), (Hanafi \& Breliastiti, 2016) yang mengatakan bahwa kepemilikan intitusional tidak berpengaruh terhadap financial distress.

\section{Pengaruh Komisaris Independen Terhadap Financial Distress}

Dari hasil uji regresi logistik mengemukakan bahwa komisaris independen berpengaruh terhadap financial distress. Dari haasil penelitian ini menerima hipotesis ketiga $\left(\mathrm{H}_{3}\right)$ yang mengatakan bahwa komisaris independen berpengaruh negatif terhadap financial distress. Perusahaan yang memiliki proporsi komisaris independen yang semakin besar maka perusahaan tersebut mengalami financial distress akan semakin kecil. Hasil penelitian ini sama dengan yang dilakukan oleh (Mafiroh \& Triyono, 2016), (Helena \& Saifi, 2017)yang mengatakan bahwa komisaris independen berpengaruh terhadap financial distress. Namun berbeda dengan penelitian (Damayanti \& Kusumaningtias, 2020) yang mengatakan bahwa komisaris independen tidak berpengaruh terhadap financial distress.

\section{Pengaruh Komite Audit Terhadap Financial Distress}

Dari hasil uji regresi logistik menunjukan bahwa komite audit mempunyai pengaruh terhadap financial distress. Hasil penelitian tersebut menerima hipotesis keempat $\left(\mathrm{H}_{4}\right)$ yang menyatakan bahwa komite audit berpengaruh positif terhadap financial distress. Komite audit mampu menghindari kemungkinan kondisi terjadinya financial distress pada perusahaan. Semakin banyak anggota komite audit memudahkan kesepakatan keputusan dalam melakukan kinerjanya. Hasil penelitian ini sesuai dengan penelitian yang dilakukan oleh(Damayanti \& Kusumaningtias, 2020), (Mafiroh \& Triyono, 2016) yang mengatakan bahwa komite audit berpengaruh terhadap financial distress. Namun berbeda dengan penelitian(Helena \& Saifi, 2017), (Ananto et al., 2017)yang menyatakan bahwa kepemilikan intitusional tidak berpengaruh terhadap financial distress.

\section{Pengaruh Leverage Terhadap Financial Distress (sebagai variabel kontrol)}

Hasil pengujian regresi logistik menunjukan leverage dalam penelitian ini tidak berfungsi sebagai variabel kontrol dan tidak sesuai dengan yang diprediksi. Dengan begitu, leverage yang baik belum tentu memberikan informasi yang bagi bagi kreditur atau investor. Dikarenakan leverage dilihat dari hutang perusahaan tidak mampu menjadi patokan untuk mengukur terjadinya financial distress. Hasil penelitian ini sejalan dengan penelitian yang dilakukan oleh (Ananto et al., 2017) yang mengatakan bahwa leverage tidak berpengaruh terhadap financial distress, berbeda dengan yang dilakukan oleh (Nurmayanti, 2017), (Mafiroh \& Triyono, 2016) dalam penelitiannya mengatakan bahwa leverage berpengaruh terhadap financial distress.

\section{Pengaruh Profitabilitas Terhadap Financial Distress (sebagai variabel kontrol)}

Dari hasil uji regresi logistik menunjukan profitabilitas dalam penelitian ini berfungsi sebagai variabel kontrol dan sesuai dengan yang diprediksi. Profitablitas yang baik memberikan sinyal yang baik kepada para investor. Hal ini terjadi kerana laba yang perusahaan yang tinggi menghindarkan perusahaan dari moment financial distress. Hasil penelitian tersebut sejalan dengan yang dilakukan oleh(Santoso et al., 2018), (Afifah, 2019) dalam penelitiannya mengatakan bahwa profitabilitas berpengaruh terhadap financial distres, berbeda dengan yang dilakukan oleh (Rahmawati \& Khoiruddin, 2017) dalam penelitiannya mengatakan bahwa profitabilitas tidak berpengaruh terhadap financial distress.

\section{Pengaruh Ukuran Perusahaan Terhadap Financial Distress (sebagai variabel kontrol)}

Dari hasil uji regresi logistik memperlihatkan ukuran perusahaan dalam penelitian ini tidak berfungsi sebagai variabel kontrol dan tidak sesuai dengan yang diprediksi. Dengan demikian, ukuran perusahaan yang baik tidak dapat memberikan informasi bagi kreditur ataupun investor. Hasil penelitian ini sejalan dengan penelitian yang dilakukan oleh (Ananto et al., 2017) yang menyatakan bahwa ukuran perusahaan tidak berpengaruh terhadap financial distres, berbeda 
dengan penelitian yang dilakukan oleh(Santoso et al., 2018), (Rahmawati \& Khoiruddin, 2017)yang menyatakan bahwa profitabilitas berpengaruh terhadap financial distress.

\section{KESIMPULAN}

Penelitian ini menguji dan menganalisis pengaruh kepemilikan manajerial, kepemilikan institusional, komisaris independen, komite audit, dan leverage, profitabilitas, ukuran perusahaan sebagai variabel kontrol terhadap financial distress pada perusahaan manufaktur yang terdaftar di Bursa Efek Indonesia tahun 2017-2019. Berdasarkan hasil analisis menunjukkan bahwa komisaris independen berpengaruh negatif terhadap financial distress. Hasil ini mengindikasikan bahwa keberadaan kepemilikan manajerial tidak berpengaruh terhadap financial distress, jumlah kepemilikan saham oleh manajerial tidak mampu mempengaruhi aktivitas manajemen dalam mengelola perusahaan. Sedangkan kepemilikan institusional berpengaruh terhadap financial distress, bagaimanapun hasil kerja dari para manajer untuk menigkatkan kinerja perusahaan berkaitan dengan besarnya kepemilikan institusional dari perusahaan. Komisaris independen mampu bertindak sebagai mekanisme pengawasan yang efektif untuk menghindarkan perusahaan dari kondisi financial distress. Komite audit berpengaruh terhadap financial distress, hasil ini mengindikasikan bahwa keberadaan komite audit memberkan kemudahan kesepakatan dalam kinerjanya. Tidak sesuai dengan yang diprediksi, variabel leverage sebagai variabel kontrol, yaitu tidak berpengaruh terhadap financial distress. Sementara itu, variabel kontrol profitabilitas sesuai dengan yang diprediksi karena profitabilitas berpengaruh negatif signifikan terhadap financial distress. Dan pada variabel kontrol ukuran perusahaan tidak sesuai dengan yang diprediksikan, yaitu karena ukuran perusahaan tidak berpengaruh terhadap financial distress.

\section{REFERENSI}

Ananto, R. P., Mustika, R., \& Handayani, D. (2017). Pengaruh Good Corporate Governance (GCG), Leverage, Profitabilitas dan Ukuran Perusahaan Terhadap Financial Distress Pada Perusahaan Barang Konsumsi yang Terdaftar di Bursa Efek Indonesia. Jurnal Ekonomi dan Bisnis Darma Andalas, Vol. 19, No. 1, Hal. 92-105.

Anjana, V. (2017). Pengaruh Kepemilikan Institusional, Kepemilikan Publik, Dewan Direksi, Komite Audit, Dewan Komisaris, Likuiditas, Leverage, dan Ukuran Perusahaan terhadap Financial Distress . Skripsi.

Ayu, G., Yulianeu, \& Fathuni, A. (2017). Analysis og Effect of Good Corporate Governance, Financial Perfomance and Firm Size on Financial Distress in Property and Real Estate Company Listed BEI 2012-2016. Jurnal Akuntansi, 1-10.

Damayanti, N. D., \& Kusumaningtias, R. (2020). Pengaruh Corporate Governance Terhadap Financial Distress Pada Sektor Perusahaan Jasa Infrastruktur, Utilitas dan Transportasi di Bursa Ever Indonesia Periode 2015-2017. Jurnal Akuntansi Unesa, 8(3).

Ghozali, I. (2011). Aplikasi Analisia Multivariate dengan Program IBM SPSS 19. Semarang: Badan Penerbit Universitas Diponegoro.

Hanafi , J., \& Breliastiti, R. (2016). Peran Mekanisme Corporate Governance dalam Mencegah Perusahaan Mengalami Financial Distress . Jurnal Universitas Bunda Mulia, 1(1), 195220.

Hartanti, D. R., \& Hatane, E. (2017). PENGARUH CORPORATE GOVERNANCE TERHADAP FINANCIAL DISTRESS PADA PERUSAHAAN SEKTOR BARANG KONSUMSI DAN PERDAGANGAN YANG TERDAFTAR DI BURSA EFEK INDONESIA. Akuntansi Bisnis Universitas Kristen Petra, Vol. 5, No. 2, H 505 - 516.

Helena, S., \& Saifi, M. (2018). PENGARUH CORPORATE GOVERNANCE TERHADAP FINANCIAL DISTRESS (Studi pada perusahaan transportasi yang terdaftar pada Bursa Efek Indonesia periode 2013-2016). Jurnal Administrasi Bisnis (JAB), Vol. 60 No. 2.

Jasen, M C; Meckling, W H;. (1976). Theory of the firm : Managerial Behavior. Journal if Financial Economics, 305-360. 
Juniarti, E. (2013). Pengaruh Good Corporate Governance, Dampaknya Terhadap Prediksi Financial Distress Pada Sektor Aneka Industri dan Barang Konsumsi. Jurnal Akuntansi Bisnis Universitas Kristen Petra, 1(2), 1-13.

Mafiroh, A. (2016). Pengaruh Kinerja Keuangan dan Mekanisme Good Corporate Governance Terhadap Financial Distress. Naskah Publikasi.

Mafiroh, A., \& Triyono. (2016). Pengaruh Kinerja Keuangan dan Mekanisme Corporate Governance Terhadap Financial Distress. Riset Akuntansi dan Keuangan Indonesia, 1(1).

Putri, R. S. (2020). Pengaruh Mekanisme Corporate Governance Terhadap Financial Distress (Studi Empiris Perusahaan Manufaktur yang Terdaftar di Bursa Efek Indonesia Tahun 2016-2018).

Rahmawati, D., \& Khoiruddin, M. (2017). Pengaruh Corporate Governance dan Kinerja Keuangan dalam Memprediksi Kondisi Financial Distress. Manajement Analysis Journal, 6(1), 2-12.

Triswidjanti, M. S. (2017). Implementasi O-Score Model untuk Memprediksi Financial Distress Perusahaan. Studi pada Perusahaan Manufaktur Sub Sektor Tekstil dan Garmen yang Terdaftar di Bursa Efek Indonesia Periode 2011-2015. Administrasi Bisnis, 50(1).

Yoon, E., \& Jang, S. C. (2005). The Effect of Financial Leverage on Profitability and Risk of Restaurant Firms. Journal Akuntansi.

Yudha, A., \& Fuad. (2014). Analisis Pengaruh Penerapan Mekanisme Corporate Governance Terhadap Kemungkinan Perusahaan Mengalami Kondisi Financial Distress. Diponegoro Journal of Accounting, Vol. 3, No. 4, Hal. 1-12. 